\title{
"El padre ya no es más el jefe de la familia”. Género, familia y quiebre generacional desde la óptica liberal-conservadora de El Burgués (1971-1973)
} \author{
liberal-conservative focus (1971-1973) \\ Martin Vicente \\ Instituto de Geografia, Historia y Ciencias Sociales, \\ CONICET - Universidad Nacional del Centro de la \\ Provincia de Buenos Aires, Argentina \\ vicentemartin28@gmail.com
}

"Father ain't no longer the family boss". Genre, family and generational break from El Burgués (The Burgeois)

DOI: https://doi.org/10.24215/25457284e121

Recepción: 12 Octubre 2019

Aprobación: 10 Marzo 2020

\section{RESUMEN:}

El artículo analiza cómo la revista liberal-conservadora argentina El Burgués (1971-1973) presentó las cuestiones de género, familia y cambio generacional. La publicación se presentó buscando dar centralidad a la identidad liberal en diálogo con pautas de otras expresiones de derechas, utilizando criterios del nuevo periodismo y apelando al humor irónico. Si la imposibilidad de asentar un modelo político posperonista en el mundo de la guerra fría definió las inquietudes políticas del quincenario, los cambios de "los largos años sesenta” fueron centrales en su mirada sobre los ejes de este artículo, que redundaron en una lectura política de los fenómenos de índole social y cultural.

Palabras Clave: El Burgués, Liberal-Conservadurismo, Derechas, Género, Familia, Cambio Generacional.

\begin{abstract}
:
The article analyzes how the Argentine liberal-conservative magazine El Burgués (The Burgeois) (1971-1973) presented the issues of gender, family and generational change. The publication presented itself seeking a centrality for the liberal identity in dialogue with guidelines of other right-wing expressions, using new journalism criteria and appealing to ironic humor. If the impossibility of establishing a post-Peronist political model in the Cold War world defined the political concerns of the fortnight, the changes of "the long sixties" were central to its approach on the axes of this article, wich resulted in a political reading of social and cultural phenomena.
\end{abstract}

KEYwORDs: El Burgués (The Burgeois), Liberal-Conservatism, Right-Wings, Gender, Family, Generational Break.

\section{INTRODUCCIÓN}

Editada en el complejo contexto de los años 1971 a 1973, la revista liberal-conservadora El Burgués se colocó ante el panorama político y mediático argentino con posiciones enfáticas. Reivindicó las tradiciones liberal y conservadora junto con ideologías que postulaba como convergentes, como el republicanismo y la democracia cristiana. Buscó postularse diferenciándose del panorama de publicaciones de actualidad política de esos años, a las que criticó abiertamente, y retomó pautas de la renovación periodística propia de la década de 1960, las que llevó hacia la derecha. Se promovió, así, como una experiencia que combinaba la apelación a recrear el liberal-conservadurismo atendiendo su doctrina y la renovación internacional de las derechas, la cual reclamaba para el ámbito local. Desde ese sitio buscó convocar a las identidades liberal-conservadoras a asumirse en el espacio político, para enfrentar lo que entendía como un panorama nacional dominado por el populismo y el ascenso de la nueva izquierda, en una geopolítica global donde temía la victoria del comunismo en la dinámica de una polaridad que, con el ascenso chino, sumaba un nuevo jugador al conflicto entre Estados Unidos y la Unión Soviética. 
Tan explícitas posiciones, sin embargo, lejos estaban de dar un rostro uniforme a un quincenario que mostraba una paleta de intereses y formas expresivas sumamente amplias. Combinaba notas de actualidad política con ensayos de corte teórico e historiográfico, sumándole a ambos el uso de diversas viñetas humorísticas que daban a la revista un tono ácido y zumbón ausente en los grandes referentes del espacio liberal-conservador local, que la acercaban tanto a la estética del nuevo periodismo propio de la década previa como a una publicación liberal-conservadora menor, El Príncipe (1960-1965).

Motorizada por el periodista político Roberto Aizcorbe, con una tirada de 20.000 ejemplares (intermedia para la época, cuando Argentina poseía el mayor mercado revisteril de la región), los 64 números de $E l$ Burgués apelaron a la construcción de un público liberal, pero fueron leídos también por fuera de ese espacio (Carman, 2015). ${ }^{1}$ Ello, por momentos, alimentó las polémicas que la revista abrió hacia otras publicaciones o los intercambios con firmas que, sin ser parte del quincenario, podían coincidir con sus posiciones. Esto último dio a las páginas burguesas uno de sus perfiles más notorios: la circulación de artículos de grandes nombres de la nueva derecha internacional y el abanico de colaboradores locales, que presentaba un mapa del nuevo rostro del liberalismo de derecha y congregaba liberal-conservadores, neoliberales, neoconservadores o liberales doctrinarios.

Una de las características más notables del liberal-conservadurismo argentino en la época fue la primacía de la política, que subsumió otras expresiones de lo social a una lectura en clave politicista (Vicente, 2014; Morresi y Vicente, 2017), rasgo que, en el quincenario, sin embargo, se combinó con una atención especial a los cambios socio-culturales y estéticos. La politización de lo socio-cultural tuvo el mismo sentido y la misma centralidad que en el resto del universo liberal-conservador local, pero las peculiaridades de la revista otorgaron a estas facetas un sitio destacado que, sin embargo, aparecía siempre ligado a una pauta política. ${ }^{2}$ A diferencia de las derechas nacionalistas o integristas, marcadas por una concepción autoritaria y tradicionalista sobre las cuestiones de género, familia y cambio generacional (McGee Deutsch, 2005; Echeverría, 2009; Rodríguez, 2011), las derechas liberales propusieron un enfoque más dinámico que, inclusive, hizo de las relaciones con las conceptualizaciones clásicas y los diagnósticos coyunturales de otras derechas una clave de sus transformaciones. Lejos de los modos escandalizados o belicosos con que las derechas nacionalistas o populistas enfocaron el humor (Galván, 2013; Besoky, 2016a), las páginas burguesas se aproximaron antes a los tonos desenfadados de las revistas humorísticas de la época (Burkart, 2017).

Como ha marcado la bibliografía reciente, dentro de los cambios propios de la larga década de los sesenta, las cuestiones vinculadas al cambio generacional, las cuestiones de género y el orden sexual y familiar fueron centrales (Cosse, 2012; Felitti, 2012; Manzano, 2017). Por eso, aparecieron entre las que mayor atención suscitaron en las páginas de la revista, que asumió esas dinámicas, tanto con evidente preocupación cuanto con un humor marcado por la causticidad. En este artículo analizaremos cómo esos tópicos fueron representados por El Burgués, centrándonos en las prácticas humorísticas. El eje del trabajo es mostrar cómo el liberal-conservadurismo del quincenario se apoyó en la renovación expresiva del nuevo periodismo para ampliar hacia las pautas de otras expresiones de derecha su gramática política. Para ello, en primer lugar, presentaremos el sitio burgués en un doble contexto: primero, el del universo liberalconservador y el mediático que actuaron como referencia para posicionarse; luego, nos detendremos sobre las representaciones que los temas señalados tuvieron en el quincenario. Allí, en un apartado para cada uno de los tópicos, se otorgará centralidad a la cuestión del rol de la mujer y la diferencia socio-cultural y política con el del hombre (el modo en que la revista entendía la cuestión de género), ya que determinaba los siguientes, como marcaremos. Finalmente, ensayaremos una conclusión que reposicione lo presentado.

\section{2. "EN LA DÉCADA DEL '70, LOS BURGUESES ESTÁN DE VUELTA"}

Con la frase precedente, Aizcorbe marcaba que era hora de recuperar, renovadas, las tradiciones liberal y conservadora, luego de cinco décadas de "abdicación" frente a los fenómenos de masas. Ante un mundo 
donde, en la lectura del director, el comunismo amenazaba con quebrar la bipolaridad que había marcado la guerra fría, y en un contexto nacional que describía signado por el peso del populismo, el avance de la nueva izquierda y la no resolución de la cuestión peronista, Aizcorbe alentaba a los burgueses a consolidar su identidad política, a dejar de estar, repitiendo a Arthur Koestler, en retirada. Lo hacía, como señalamos, alentando el reconocimiento a las tradiciones burguesas (liberal, conservadora, republicana, democristiana) y la atención a las diversas renovaciones teóricas que llegaban desde Europa y los Estados Unidos, que se sumaban a las firmas locales.

Así, notas del ensayista francés Raymond Aron, del economista estadounidense Milton Friedman o del tradicionalista católico húngaro Thomas Molnar se cruzaban con textos de autores locales como el economista Roberto Alemann, el diplomático Manuel Malbrán, el abogado Armando Ribas o el militar y ensayista Carlos Sánchez Sañudo. Los contactos del director Aizcorbe, quien había obtenido gran visibilidad con su cobertura de "el Cordobazo" en 1969 para Primera Plana, motorizaron tanto al pequeño grupo fijo de la revista como los vínculos nacionales e internacionales. La salida de diversos periodistas de la editorial liderada por Jacobo Timerman, de impacto en el universo mediático porteño, fue el paso previo para conformar la revista (Mochkofsky, 2003). Con menos de 40 años, Aizcorbe tenía experiencia de coordinación, ya que había sido secretario de la sección Política en Primera Plana, luego de desempeñarse en Internacionales. En la estructura del quincenario eran claves las firmas de los columnistas políticos Martín Ariza y Daniel Gigena Lamas, ${ }^{3}$ quienes alternaban notas de coyuntura con textos de aliento ensayístico, junto con los roles del fotógrafo V. Alfieri, quien articulaba la estética de la revista, y de Mona Alfonso en las traducciones, todos bajo la coordinación de Susana Oliveira.

En ese sentido, el llamado del director, clave de la posición editorial de la revista, era una toma de posición político-identitaria, un desafío a quienes postulaba como antagonistas, y una búsqueda de construir un público propio. Por eso mismo, el quincenario buscaba una estética visual y una narrativa que la ligaban a la renovación periodística de la década de los sesenta antes que a los formatos imperantes en el universo liberalconservador local de medios casi centenarios como La Nación y La Prensa o de revistas de corte teórico como Ideas sobre la Libertad. En un punto, El Burgués construyó su identidad en el cruce de tradición y renovación, atención a la coyuntura y lecturas de la historia, apelación a la alta cultura y al humor descarnado y, en suma, politización de la cultura (Vicente, 2019).

La revista criticaba tanto a los grandes medios como a editores claves en la etapa, con quienes Aizcorbe había trabajado, como Jacobo Timerman (a quien vapuleaba por sus simpatías con la cultura de izquierda) o Cesare Civita (sobre quien colocaba el mote de monopólico) y bregaba por imponer una fórmula mixta entre los clivajes tradicionales del universo liberal-conservador y el nuevo periodismo. ${ }^{4}$ Aizcorbe definía El Burgués como una revista que pedía al libro sus formas y sus temas centrales a la actualidad, que procedía "sin ambagues [sic], con gracia, sin solemnidad" (EB, 3, p.3). ${ }^{5}$ De allí la fuerte presencia del humor, tanto en viñetas como fotografías, en tapas como en intervenciones sobre las notas, donde destacaba el principal foco visual de la revista, la sección en papel ilustración que en la mitad de cada número y sin paginado, jugaba con diversos recursos visuales de una a otra página, como la oposición, la continuidad o la comparación. Así, el formato estético que la revista había tomado tanto de la italiana Il Borghese como de la renovación periodística local, especialmente de Primera Plana (readaptando luego en parte las coordenadas de la mencionada El Príncipe), permitía que el juego visual se destacase en el conjunto del diseño general (Figuras 1 y 2 ). ${ }^{6}$ El uso político de las imágenes era parte central del discurso burgués, entroncando con el destacado sitio que allí ocupaba el humor, como modo de sumar capas interpretativas al análisis de la actualidad que ocupaba la atención primordial de la revista. Reírse de la realidad era un modo de intervención ideológica que se explicitaba, incluso de modo gozoso, pero que, como se verá, no excluía ciertos giros hacia un tono más agrio y sombrío.

El Burgués completaba su estética con publicidades sobrias, tanto de productos ligados a consumos de alto nivel (automóviles, champagne) y al bon vivre (whisky, cigarrillos), como a populares (cerveza Quilmes o ropa Grafa). Pese a las posiciones contrarias al nacionalismo económico o el desarrollismo, en la revista se 
publicitaban la petrolífera de bandera YPF o la empresa Siam, símbolo de la industria desarrollista. Algunas publicidades, incluso, jugaban con el humor que campeaba en las páginas de la publicación: el restaurante Sans Gene se publicitaba tanto ofreciendo "Salas privadas para reuniones empresarias y petit convenciones", como bajo el slogan "el no tan caro". La publicidad de la revista apuntaba a un público mayormente masculino, pero sin cerrarse a los criterios de distinción que buscaban al self made man, típicos del nuevo periodismo de la década anterior, y sobre los que ironizaron desde Quino en Mafalda a María Elena Walsh en sus canciones (Pujol, 2002; Cosse, 2014). Se pasaba mayormente por alto los consumos destinados a la mujer, los jóvenes o los niños, e incluso casi se dejaba de lado los familiares. Si bien en gran parte la publicidad dependía de la voluntad de los anunciantes, el estilo de la publicación imponía ciertas pautas estilísticas que trazaban un perfil con enfoque masculino adulto, a tono con los burgueses que Aizcorbe buscaba (re)crear como sujeto político. Como veremos luego, la burguesa aparecía de modo indirecto, como respuesta a modelos criticados o como identificación con pautas que la revista reconocía, antes que como un público definido de modo taxativo e identitario.

El mismo Aizcorbe entendía que el ciclo histórico donde la publicación había nacido era un proceso complejo, al que se debía responder con un criterio plenamente político-identitario, de allí que la apuesta por construir un lector con identidad política fuera central. Por ello destacaba (como adelantamos) que en las cinco décadas previas las tendencias masificadoras y centralistas habían aplastado al sujeto político que la publicación proponía rescatar, y que la erección de ese posicionamiento era un constructo político: "Es que el burgués no nace, se hace en la elevación responsable y diaria de su persona, contra las tendencias masivas o centralizadoras. Esta revista -que no pretende el monopolio de la verdad-sale para él, y para los que quieran venir" (EB, 1, p.3). ${ }^{7}$ La renovación internacional de las derechas obraba como marco general para proponer un retorno del sujeto burgués, que en la Argentina enfrentaba el desafío de reaparecer para superar el callejón, hasta allí sin salida, de la etapa posperonista. "En la década del '70, los burgueses están de vuelta", señalaba Aizcorbe ya en su primer "Envío" editorial (EB, 1, p.3). Por ello la revista proponía oficiar como un ariete para que ese sujeto político ganase un sitio central en el universo ideológico argentino, para articular lo que, desde su primera tapa, entendía como "La mayoría silenciosa". Así, se llamaba una y otra vez a la convergencia de los liberales y a promover la lectura de sus páginas como modo de fortalecer esa identidad: poner El Burgués en manos de un liberal potencial era, rezaba su aviso, la mejor forma de convertirlo "en un liberal activo". La necesidad de recrear una posición identitaria fue un problema central para el universo liberal argentino luego del derrocamiento del peronismo en 1955 (Vicente, 2014; Haidar, 2016), y la revista lo explicitaba.

La irresolución de la cuestión peronista era el marco de lo que el director entendía como una "democracia masoquista". Para Aizcorbe, se trataba de un problema suscitado en el inmediato posperonismo por la estrategia de Arturo Frondizi de buscar gobernar con apoyo, tanto peronista como antiperonista, que se había extendido a la mayoría de la política argentina, impidiendo la correcta resolución del desafío que el peronismo suponía para el sistema político local. Había aquí una reflexión del propio Aizcorbe sobre su pasado, puesto que había sido militante frondizista en su juventud. Pero, centralmente, se trataba de un pedido a los sectores antiperonistas para lograr ser una verdadera alternativa ante los políticos y militares que no hacían sino volver una y otra vez sobre alianzas con el justicialismo, buscar sus votos o apelar a mecanismos que el director calificaba como "integracionismo", a los que no escapaban siquiera los propios liberales (EB, 1, p. 5). ${ }^{8}$ La segunda etapa de la Revolución Argentina era vista desde la óptica burguesa como un momento liminar: la apertura al diálogo político con los partidos tradicionales fue calificada desde el quincenario como la apertura de una auténtica caja de Pandora. Por ello, la tapa del número 14 titulaba "Milicos eran los de antes", bajo una imagen de la "conquista del desierto" de 1879, con la figura icónica de Julio Roca, quien un año después lideraría un gobierno que el liberal-conservadurismo argentino leía como ejemplar, bajo el lema "Paz y administración". Era, justamente, lo que no podían lograr los milicos del equipo del dictador Alejandro Lanusse. La portada fue una de las más resonantes del quincenario y, en sus memorias, el propio 
Cano Lanusse señalaría a la revista como portavoz de una crítica "de extrema derecha" liberal, ciega a su proyecto de reincorporar de modo pacífico al justicialismo a la política electoral (Lanusse, 1994).

El Burgués presentaba una lectura posicionalmente binaria de la política, que compartía con las líneas centrales del liberal-conservadurismo luego de 1955. Allí se argumentaba que la democracia liberalrepublicana era la contracara de los fenómenos totalitarios, en los que incluía tanto a los de orden dictatorial o revolucionario, como a las democracias populistas (Vicente, 2014; Morresi y Vicente, 2017). En ese sentido, las notas de intelectuales internacionales eran centrales para trazar un perfil antitotalitario, en el que la sofisticación de las reflexiones teóricas, historiográficas y culturalistas que aparecían en esas notas que escapaban a la coyuntura, daban a la revista un cariz que complejizaba el posicionamiento binario y agonal con el que entendía la política. Ello se llevaba al paroxismo a la hora del humor: así, los tándems armados en base a oposiciones binarias (capitalismo-comunismo, izquierda-derecha, peronismoantiperonismo, conservadurismo-progresismo) reforzaban tanto el eje de impacto de sus provocaciones como el perfil identitario de la publicación. Algunas de sus ironías tuvieron fuerte repercusión, como la mencionada tapa con Roca, otra donde una granada envuelta para regalo deseaba "Felices Fiestas" con la firma de Montoneros en la tapa del número 19, o las imágenes de María Estela Martínez bailando en un club nocturno caribeño, que acabaron impactando en el cierre de la publicación, como veremos.

\section{MuJERES, VESTIDOS Y FEMINISMO}

La imagen de la mujer era clave en El Burgués por tres motivos centrales. Primero, la cuestión de género se resumía en leer los distintos y cambiantes roles de la mujer en las sociedades contemporáneas (en relación, centralmente, con el hombre y desde allí con la familia y el cambio generacional). Luego, por un lado, las tapas de la revista estaban mayormente ilustradas por la imagen de una modelo que jugaba con la simbolización del tema principal del número, con una estética que por momentos se acercaba a la de la revista Playboy, en un juego sobre el límite estético para una revista de actualidad. ${ }^{9}$ Por otro lado, la imagen femenina era utilizada permanentemente para graficar transformaciones sociales, culturales y políticas, en especial en torno a los diversos sentidos de la "liberación femenina", un término epocal sobre el que el quincenario no ahorró ironías. Así, se pueden apreciar, entre otras estrategias, el uso del cuerpo femenino como símbolo de diversos status (la mujer modelo graficaba al hombre exitoso o la elegancia clásica implicaba una posición social destacada y un sentido estético) y de distinción en el sentido analizado por Pierre Bourdieu (2012). También, la búsqueda de anticipar la atención del lector y jugar con ello ("Con la izquierda en la cabeza", titulaba una tapa donde una modelo se cubría apenas el seno izquierdo, EB, 32) (Figura 3). Finalmente, la estética femenina aparecía como vehículo de comparaciones ("Las horcas caudinas de los partidos débiles" con la imagen de Puerta de Hierro, la residencia española de Perón, frente a "Las horcas caudinas del sexo fuerte" con una joven en minifalda, abierta de piernas y enfocada en ángulo contrapicado, EB, 2). Así, el uso de la imagen femenina podía ir tanto desde un semidesnudo que ironizaba sobre la política cotidiana del país (“¿Llegó carta de Madrid?”, se preguntaba un epígrafe ante una modelo que sólo cubría sus senos y entrepierna con cartas, bromeando con la correspondencia madrileña de Perón, EB, 3) (Figura 4), a remedar figuras polémicas como la de Lolita, en una tapa dedicada a la problemática educativa, pasando por las fotografías de jóvenes feministas, hippies o militantes políticas sobre las que la publicación colocaba su mirada vitriólica $(\mathrm{EB}, 9)$.

$\mathrm{Al}$ mismo tiempo que la revista utilizaba la imagen femenina con especial hincapié en los semidesnudos o las imágenes tipificadas como sugerentes, el uso de ciertos desnudos o la representación de cuestiones sexuales en las artes contemporáneas o populares (sin considerarlas idénticas en sentido estético) eran objeto de su crítica. Así, bajo la imagen de dos estatuillas donde la primera era una mujer de mediana edad con vestido y cabello largos y un cerdito en manos, y la segunda una joven desnuda de cabello corto desgreñado, el epígrafe marcaba: "El arte popular cambia. Los vestidos desaparecen, el puerco queda" (EB, 28). Parte de la crítica sobre las vanguardias artísticas o el arte centrado en detalles escatológicos aparecía enfocada en considerarlo 
propio del bagaje directo o indirecto de la izquierda en el primer caso y del repertorio bajo del populismo en el segundo (Ostiguy, 1997). Esto puede resumirse en las palabras que usaba la revista en sus epígrafes con tono de slogan: "Para la izquierda 'el arte es un arma", "Y el 'feminismo' también" (EB, 30). De allí que artistas que para la publicación retrataban la decadencia de las sociedades occidentales, como Federico Fellini, fueran criticados una y otra vez, aun si ello refería a la adaptación de un clásico (sí que pleno de erotismo y escenas sexuales) como El Satiricón de Petronio. Lo mismo ocurría con las críticas a otro director italiano como Lucino Visconti, a quien dedicaban ironías por una presunta relación con Björn Andersen, el adolescente actor de Muerte en Venecia de quien se prenda el protagonista del film, compuesto por Dick Bogarde (EB, 2; EB, 9). Se trataba de estetas de la "pornocracia" (EB, 39), "cineastas de la banalidad y la pornografía" (EB, 40). El cine italiano era permanentemente foco de crítica, tanto por sus temas como por las posiciones de referentes como el mismo Fellini o Sofía Loren, de simpatías socialistas. Precisamente con la propia Loren, como ocurría con otra actriz de posición progresista como Brigitte Bardot, las críticas se combinaban con las lecturas de las intérpretes como símbolos sexuales, por lo que el humor iba siempre acompañado de sentidos vinculados a lo sexual o se elegían imágenes de tono procaz para subrayar las ironías.

Esos nombres centrales de la filmografía del viejo continente se sumaban al elenco de artistas locales sobre los que El Burgués lanzaba sus comentarios ácidos, en un abanico que abarcaba, entre otros, al escritor Julio Cortázar, la actriz Nacha Guevara o el novelista Manuel Puig, fuera por sus posicionamientos políticos, por sus orientaciones sexuales o por las características estéticas de sus creaciones. También se ironizaba sobre instancias como "El Contrasalón" (organizado como respuesta a la censura en el Salón Nacional de Artes Plásticas en 1972) o instituciones vanguardistas como el Instituto Di Tella. Sin embargo, a esta amplia paleta de nombres la revista no oponía un canon artístico-estético, sino que este se desprendía como el contorno externo de aquello sobre lo que ironizaba permanentemente. En los pliegues de esos sentidos estéticos aparecía una y otra vez la ocasión para la crítica política: como ocurría con el liberal-conservadurismo de la época, la centralidad de la política tomaba para sí también los sentidos de lo estético, hasta anular su autonomía relativa (Vicente, 2014).

De la mujer como vehículo de ironía estética a los sentidos de las relaciones entre arte y sociedad, se podía pasar al juego político directo y el límite con el chiste verde, basado en lo sexual y el vocabulario altisonante: "Con esa boca puede hacer lo que quiera", rezaba el epígrafe de la foto donde una modelo en bikini sostenía una flor entre sus labios. Arrodillada y mirando con firmeza a la cámara, la frase jugaba con las representaciones típicas del sexo oral, pero inmediatamente la dinámica se completaba con la contrapágina donde aparecía Golda Meir: "Con esa boca puede decir la verdad". La premier israelí aparecía en el (breve) canon de políticos elogiados por la revista, que compartía las posiciones liberal-conservadoras de entender a Israel como una cuña occidental en el mundo del Este (Nash, 1987; Vicente, 2014), por lo que al tiempo que se mofaba de los combatientes palestinos olvidaba el abrazo de Meir con Eva Perón en su primera visita al país en 1951 y sus elogios al peronismo (EB, 5). Si la modelo representaba un canon de belleza que habilitaba la complicidad con el público lector para introducir el contrapunto político (un proceder típico del contrato de lectura de la revista), diversos íconos femeninos podían actuar como contracaras entre sí. Así, la comparación entre Marilyn Monroe en la allí ya icónica escena de La comezón del séptimo año, con pollera blanca que flameaba hacia su cintura, y la imagen de una mujer que subía una escalera de espaldas vestida con un conjunto a-gogó de pantalón corto, permitía no sólo una crítica a los cambios en el vestir sino un juicio sobre dos tipos de belleza femenina. Por un lado, la mujer curvilínea de la cual Monroe devino símbolo, del otro el modelo Twiggy representado por la delgadez, la figura vertical y la estética moderna (EB, 31), ${ }^{10}$ (Figura 5), parte de las transformaciones sobre las que el quincenario no ahorraba comentarios mordaces.

Los símbolos tradicionales de distinción estética, sin embargo, eran objeto de mofa cuando aparecían fuera de lugar: así, se podía criticar el glamour si este era el de Perón, improcedente en "el primer trabajador", o destacar que las asistentes a un acto en apoyo al comunismo vietnamita aparecían "emperifolladas". Si el aspecto del líder justicialista era comparado con el de la vedette estadounidense Sally Rand, donde sí era 
correcta la imagen glamorosa, las militantes argentinas eran colocadas como simples rebeldes burguesas frente a la imagen de una madre que, en Vietnam, huía con sus hijos del asedio comunista (EB, 3; EB, 50). La distinción no era, por ende, asequible a todos, así como el consumismo era también criticado, por ejemplo cuando se señalaba que "La madre de consumo... ha tenido el hijo que se merece", mientras las imágenes contraponían a una joven embarazada que llevaba un vestido moderno y un niño que remedaba la imagen satírica de la revista Mad (EB, 50) (Figura 6). En estos casos, se trataba de críticas a la frivolidad de ciertos compromisos estéticos y políticos, que llegaba al paroxismo al contraponer "El duro peso del comunismo" y "El duro peso del capitalismo": en la primera imagen, el epígrafe era una descripción de una mujer que cargaba pesadas bolsas con tubérculos, mientras que bajo la segunda foto se trataba de una ironía: en ella, una joven tocaba despreocupadamente la guitarra en la playa. La comparación subrayaba la sentencia política con un juego estético: en tanto la primera foto era oscura, la segunda era clara, tanto como las ropas largas y básicas de la trabajadora contrapuestas con la ligera malla y las botas de diseño de la otra mujer (EB, 50).

Los compromisos ideológicos y el rol de la mujer en las transformaciones socio-políticas eran evaluados también en torno al universo católico. La tapa "Los tercermundistas" (EB, 23) presentaba a una mujer de atuendo dividido en mitades verticales: el lado derecho, larga sotana negra; el lado izquierdo, vestido moderno de falda corta (Figura 7). El corte de pelo de la modelo de portada completaba la imagen a-gogó que buscaba denunciar las desviaciones modernistas en la Iglesia católica (Zanca, 2004) (Figura 5). Ya desde el primer número, en las páginas del quincenario se alertaba sobre "la Iglesia modernista", caracterizada por un acercamiento real-político al comunismo, el rol de los sacerdotes tercermundistas y las reformas internas, tanto políticas como de culto (EB 1, p. 37). ${ }^{11}$ Así como se ironizaba sobre la ligazón entre la izquierda y la Iglesia desde una viñeta donde el sacerdote lamentaba no tener más tiempo para leer a Mao ya que debía oficiar misa, también la sexualidad de sacerdotes y monjas era objeto de mofa. Jóvenes ordenados se indignaban ante un religioso mayor por haber hecho la guerra y no el amor ("es un herético", indicaban); un sacerdote y una monja aparecían a punto de besarse, mientras ella dejaba de lado, simbólicamente, su rosario; se graficaba a los "curas sudamericanos" como guerrilleros (EB, 4); una joven despuntando el nacimiento de uno de sus senos al abrir un atuendo religioso era "La amiga del tercermundista", connotando su rol como amante (EB, 36). Muchas de las críticas que el liberal-conservadurismo realizaba sobre las transformaciones en la Iglesia aparecían aquí no sólo concentradas sino llevadas a una relación con sentidos presentes en otras expresiones derechistas. Esta estrategia retórica atravesó a las derechas argentinas en la etapa, pero también recogió una tradición donde las figuras del prelado lujurioso, el desapego a la religión de los creyentes o la desatención al culto eran figuras ya clásicas (Di Stefano, 2010; Zanca, 2012; Di Stefano y Zanca, 2013).

Las críticas a las posiciones políticas de la Iglesia tras el Concilio Vaticano II, con centralidad política, se resumían en el chiste que, en la sección de páginas ilustración, aparecía en el número 21: "Vacaciones-Para quien no guste del campo o el mar...”, “...Una buena 'garçonniére' posconciliar”: de un lado, la imagen de una mujer riendo, salpicada por gotas de agua, con el ojo de la cámara centrado en su escote y torso. Del otro, primero una foto de un hombre y una mujer, de espaldas, tomando sol entre ovejas, luego la de un departamento donde, junto a una lámina de Mao y otra de Cristo, una mujer se desabrochaba un vestido de cama escotado $(\mathrm{EB}, 21)$. Las tres imágenes connotaban sexualidad, pero el eje del humor pasaba por igualar la sexualidad distendida de las vacaciones con la levedad de los compromisos posconciliares, marcados tanto por el sexo como por el peso de la modernización confesional. Más allá de la referencia a figuras arquetípicas de las críticas a la Iglesia, el clero o los creyentes, el giro modernista hacia la izquierda o el populismo era la clave.

Sobre la mujer en esos espacios ideológicos, la revista acicateaba respecto de las relaciones entre estética y política, por ejemplo, entre las ironías dedicadas a las transformaciones en las estéticas femeninas. Las páginas burguesas criticaban tanto el atuendo que dejaba a la vista el embarazo avanzado de una asistente a un cóctel de la revista inglesa New Left Review (EB, 23), como el fútbol femenino. Este se criticaba tanto considerando que se trataba de una práctica impulsada por el feminismo, cuanto entendido como posición de izquierda (“Jugando al fútbol, ¿alumbrará al hombre nuevo?" -EB, 2) o propia de sectores social y culturalmente bajos 
(“Al fobal, Dio lo guarde..." -EB, 27). Esta última chanza recreaba lo que entendía como el habla de los sectores populares, en un sentido ya presente en las mofas sobre el peronismo clásico (Adamovsky, 2009; Nallim, 2014) (Figura 8). El contrapunto entre dos tipos de "heroína” también apelaba a las comparaciones para criticar la militancia femenina de izquierda: de un lado, el personaje Calamity Jane, interpretado por Jean Arthur en el clásico film de 1936, frente a Angela Davis, la activista afroamericana. Si la primera representaba una "heroína" de 1870 en la "conquista del Oeste" en los Estados Unidos, la segunda no era sino una "heroína" (entre sarcásticas comillas) de las que en 1970 "destruyen California" (EB, 4). No se trataba sólo del uso literal contra el irónico del término "heroína", sino que también otros significados aparecían en juego: así, se podía comparar el modo de "morir como héroes" de los soldados japoneses, con el "morir de heroína" de los adictos a las drogas (EB, 13). Las "droga partys" sobre las que la revistas descargaba sus comentarios sardónicos eran, asimismo, parangonables con eventos socio-culturales como los encuentros de hippies y con tendencias artísticas como el Living Theatre.

Si del uso de la imagen de actrices como base de la ironía se trataba, mientras la militante peronista Silvana Roth era colocada como símbolo del "Peronismo genuino" (sin que implicase un elogio, precisamente), la modelo y actriz Chunchuna Villafañe era calificada como ejemplo del "Peronismo snob" (EB, 42), conformado por jóvenes figuras del espectáculo o las artes, como la vedette Libertad Leblanc (EB, 44). Nuevamente, la estrategia de giro en los sentidos interpretativos: así como se elogiaban los modelos tradicionales de belleza femenina como Monroe o "la diosa" Rita Hayworth, mujeres que representaban similares esquemas de belleza eran objeto de la ironía por desplazamiento. Como en el caso del glamour de Perón, era la posición política la que determinaba el sentido de la estética.

En el centro de los cambios que se produjeron en "los largos años sesenta", aparecía la mujer. Como ha destacado Isabella Cosse (2012), la sexualidad prematrimonial de las jóvenes estaba en el eje de esa centralidad, que implicó trastocar prácticas de la intimidad y relaciones afectivas, creó nuevas visibilidades apareciendo como tema a considerar por el periodismo y factor a ser polemizado en el espacio público, así como coto para el mercado. El Burgués se rio de modo impiadoso sobre las pautas de esas instancias, colocando los cambios en los roles femeninos (y por ende las relaciones de género) como base de las críticas sobre los cambios socio-culturales que iban del ámbito privado al público (Cosse, Feletti y Manzano, 2014).

\section{FAMilias, PAREJAS y RAPTOS}

Como señalamos, las transformaciones abiertas en la larga década de los sesenta ofrecieron como uno de sus rostros más visibles su faceta de cambio social, cultural y político, que obturó, sin embargo, una serie de fenómenos en sentido contrario. Las derechas argentinas comprendieron esa tensión y dieron diversos argumentos, ora de tono analítico, ora de cariz escandalizado: lo que particulariza a El Burgués es el modo en que ironizó sobre una y otra instancia, a diferencia de otras derechas cuyo humor careció del sarcasmo del quincenario de Aizcorbe, que lo aproximó antes a revistas humorísticas que hacían de la actualidad su material de base, en lugar de colocarla en paralelo a expresiones derechistas donde ese estilo estaba ausente (Burkart, 2017; Besoky, 2016a). Parte de esa clave se asentó en que la revista no sacralizó ni revistió de un tono solemne a los objetos celebrados (salvo para hablar de la muerte violenta), así como no dejó de considerar con sorna a sus adversarios. El caso de la familia, entendida por las derechas argentinas bajo diversos prismas que en esos años experimentaron el impacto de las transformaciones (Cosse, 2012; Manzano, 2017), aparece como central para captar ese proceder. Así como la publicación colocaba en el eje de sus lecturas los cambios en los roles de la mujer (y con ello las relaciones de género) y el quiebre generacional, la familia aparecía como un modo de mostrar, de manera sardónica, el impacto primero de esas transformaciones. El más gráfico ejemplo lo expresaba la caricatura cuya frase titula este artículo: en ella, la familia tipo aparecía compuesta por la madre, con atuendo gitano como el usado por ciertas corrientes del hipismo, y el hijo y la hija con aspectos modernos, mientras el padre, sobriamente trajeado, aparecía de cabeza en un cesto de basura, rasgado por un gato como 
en los cartoons de Hanna-Barbera (EB, 22). (Figura 9) "El padre ya no es el jefe de la familia", resumía una serie de asunciones que circulaban en la revista: la disolución de los cánones tradicionales de familia y de autoridad de padres hacia hijos; la independización de la mujer respecto del hombre; la progresiva cercanía de los comportamientos de los adultos con los de los jóvenes; la autonomía juvenil en el mismo núcleo familiar.

El Burgués apuntaba tanto a la amenaza de destrucción de la familia como a las distorsiones a su interior que generaba el cambio socio-cultural, donde la familia era uno de los pedestales que los revolucionarios destruían, junto con la patria y la religión (EB, 6, p. 18). Un diagnóstico que había atravesado a las derechas nacionalistas y religiosas a lo largo del siglo (Echeverría, 2009; Rodríguez, 2011), encontraba en la mirada liberal-conservadora un acuerdo. Pero el giro sarcástico del quincenario, por ejemplo, plasmaba una escena donde, ante un matrimonio que se disponía a salir a recrearse, aparecía la aclaración la niñera: "Vayan tranquilos. De los chicos me ocupo yo...”. Y ella no era sino Mao-Tse Tung(EB, 7, p. 15). Las representaciones de la familia en la cultura masiva también eran insumos para la chanza política. Por ejemplo, cuando la comedia Los Campanelli aparecía desde el lema que remataba los programas, "No hay nada más lindo que la familia unida", resignificado contra los políticos de La Hora del Pueblo, que con su unidad graficaban las "abdicaciones ideológicas con tal de llegar al poder" (EB, 2).

El matrimonio era visto como una institución cuya crisis conllevaba problemas de índole privada y política, en continuidad con la transformación en los sentidos de los roles de la mujer, por ello vinculado con la cuestión de la familia y, por vía de esta, con el cambio generacional. Ejemplos de ello son la crítica sobre la concepción heteronormativa del enlace conyugal y su perfil político, por un lado, y la cuestión de la fidelidad por el otro. En el primero de los casos, la contrapágina mostraba por un lado la boda de la escritora Dawn Langley Simmons, nacida como Gordon Langley Hall. La autora estadounidense era tratada en masculino mientras se mostraba una imagen de su boda "con un garagista [sic] negro", mientras enfrente aparecía una foto del Ejército Rojo marchando. La conclusión iba de lo personal a lo (geo)político: "Si los occidentales se portan así...”, “...Estos señores llegarán bien pronto”, $(\mathrm{EB}, 2)$ en una inflexión que mostraba de qué modos el nuevo anticomunismo había imbricado las lógicas de las derechas liberales y las ultramontanas (Bohoslavsky y Vicente, 2014). En el otro caso, las páginas enfrentadas articulaban la imagen de una novia de boda bebiendo de un botellón y la de una pareja besándose en un departamento: el gesto dionisíaco de la primera signaba el olvido por vía de la bebida, el segundo representaba una escena de adulterio: "Para olvidar está el marido" (EB, 24).

En defensa de los cánones tradicionales, para la revista era necesario alejarse de gestos modernos como el hipismo (como profundizaremos luego), que implicaba "un regreso al mono" por parte del hombre, para dar paso a un gesto "conservador": el regreso del hombre a la mujer (EB, 3). El hipismo se trataba de un posible nuevo tipo de civilización, ironizaban las páginas burguesas, que no esperaba "el progreso", sino que caminaba hacia "el regreso" (EB, 9), el retorno al simio. El hipismo como cultura de las drogas y el primitivismo implicaba también dar vuelta la célebre frase de Karl Marx: "El opio es la religión de los pueblos" (EB, 21). “El mono desciende del hombre?”, preguntaba sardónicamente una tira que ilustraba la sección de cartas de lectores y mostraba las etapas involutivas del gentil hombre: burgués, hippie (con guitarra y jeringa), peronista, combatiente urbano, troglodita (arrastrando a una mujer del cabello) y finalmente simio (EB, 54, p. 46) (Figura 10). En la regresión del burgués al mono, el rapto de la mujer era la última etapa humana del personaje: una marca de cómo la revista entendía que se perdían los criterios burgueses de seducción y, por ende, de emparejamiento y reproducción.

La ruptura en esos cánones de emparejamiento iba desde la trama del cortejo hasta el sentido de las dinámicas matrimonial-familiares, que se resumía en la imagen de una mujer de mirada perdida, con un delicado vestido de novia coronado por una capelina y las manos en un gesto a medias de rezo y desencanto: "La mujer se queda sola", rezaba (valga el término) el título. En la portada, además de esa frase y de la imagen, sólo aparecía el logotipo de la revista, subrayando el sentido desolador del titular $(\mathrm{EB}, 15)$ (Figura 11). Esa soledad de un modelo de mujer (la burguesa de la revista, muchas veces esquiva pero aquí definida) 
se anclaba en las transformaciones sociales, y sobre ella se construían los diagnósticos vinculados. El quiebre generacional, veremos, profundizaba esa problemática.

\section{JóVENES, REBELDES Y MODERNOS}

En la lectura burguesa, las transformaciones sociales encontraban en la ruptura con el mundo adulto una condición socio-cultural de base: una juventud marcada centralmente por comportamientos frívolos o por actitudes desorientadas aparecía como protagonista de un paisaje generacional que era tanto argentino como internacional, y que se expresaba tanto en prácticas como en estéticas, en militancias como en discursos. La trama relacional entre generaciones era postulada por la revista con la sorna que caracterizaba sus posiciones pero, como se verá, al igual que en los temas ya presentados en un momento esa sonrisa sardónica devenía, también, mueca triste.

El “Glamour, 1940", representado por Hayworth, frente a la "Moda 'filth', 1971" era una de las formas de mostrar cómo los sentidos del vestir reflejaban cambios socio-culturales profundos. En esa doble página, frente a la imagen de la actriz una mujer vestía ropas minimalistas y llevaba la cabeza rapada, signando “(e)l envilecimiento de la imagen femenina" $(\mathrm{EB}, 15)$. Que la estrella apareciera sobre una cama y la segunda en la calle, subrayaba los sentidos que el quincenario adjudicaba a las mujeres que formaban parte de cánones estéticos que ponderaba, frente a las que criticaba. Pero esas transformaciones en las modas no implicaban sólo la pérdida de patrones consolidados de elegancia, sino también el peso de los formatos unisex ("Los viste un homosexual, y no se sabe cual [sic] es cual”, se ironizaba sobre las creaciones de Yves Saint-Laurent, el mayor autor de esa tendencia en alta costura, EB, 17) o lo que la revista entendía como símbolos militantes frívolos, como la vestimenta basada en estética guerrillera. Esta última intervención resaltaba la paradoja de promover modelos costosos con simbología revolucionaria o proletaria: “¿Los usarán las obreras o las aristócratas 'tercermundistas'?" (EB, 20). Como en la irónica historieta "Guerrilleros de papá", se trataba de posturas leves, propias de jóvenes burgueses. ${ }^{12}$ Para la revista, por ello, era la propia burguesía la que atentaba contra sí misma al dejar crecer a la izquierda, como lo graficaba una viñeta donde una representación de aquella accionaba la guillotina que le cortaría la cabeza con su mano, precisamente, izquierda (EB, 21).

La frivolidad achacada a las nuevas modas no era exclusiva de hippies o modernos, sino que el quincenario criticaba que las modas juveniles penetrasen en ámbitos otrora respetables, tal hemos visto en las críticas a la Iglesia, como los militares: así, se ironizaba sobre los cabellos largos o las redecillas para el pelo en soldados europeos como símbolo de la relajación que, tal lo señalamos, facilitaba el avance soviético sobre Occidente (EB, 22). Pero esa laxitud occidental, sin embargo, no era solo propiedad de las sociedades atlánticas, sino que el quincenario también dedicaba sus ironías al "Japón playboy" que dejaba de lado la recta resistencia del "Japón banzai" (EB, 22). La lectura central del quincenario era que las nuevas generaciones, ya parte del mundo adulto, olvidaban los sacrificios de la generación anterior, la que había ido a la guerra por el mundo libre (en el caso de los Aliados) o del mandato imperial (en el Japón) (EB, 40). ${ }^{13}$ Sin embargo, la juventud también podía ser usada como base para generar un segundo sentido, por ejemplo para marcar "La juventud busca el centro", con la imagen de una modelo donde, efectivamente, el centro de la fotografía era el centro del cuerpo de la mujer, en el que destacaban, por la ropa y el juego de iluminación, su cadera y ombligo. En la foto siguiente, se contraponía que "Los viejecitos giran a la izquierda", con la imagen del radical Eduardo Grammond (EB, 46). Es decir, la frivolidad no era sólo de los jóvenes, sino también de los mayores que, como el glamour de Perón que analizamos antes, estaba fuera de lugar. La apelación al centrismo de los jóvenes iba de la mano de los pedidos burgueses de conformar una opción liberal, entendida en la etapa como centrista por las mismas voces de este espacio, que se definía a sí mismo como "de centro" (Mansilla, 1983; Morresi, 2008; Vicente, 2014).

Era por lo antedicho que también las problemáticas generacionales aparecían como puntos para ironizar sobre la vida interna de los partidos tradicionales: si por un lado la juventud de apetencias liberales era llamada 
a dar forma a ese centro liberal-conservador, los jóvenes peronistas, radicales e izquierdistas eran burlados una y otra vez. Desde la representación del Julio César shakespeareano donde Raúl Alfonsín (representante del ala juvenil del radicalismo) se predisponía a dar cuenta del patriarca Ricardo Balbín, pasando por la pérdida de columna vertebral que ocasionaba a un Héctor Cámpora bajo registro radiográfico el privilegiar a la Juventud Peronista por sobre el sindicalismo, hasta las constantes identificaciones entre la militancia de izquierda y la drogadicción, la politización juvenil que escapara al canon burgués era objeto de ironías.

En otros casos, las representaciones de las culturales juveniles aparecían reposicionando conceptos, procesos o políticas que la revista entendía como deseables, nuevamente en el juego sobre el fuera de lugar: en una historieta, el personaje barbado "El Camarada Jeringa" (que conjugaba el izquierdismo con la drogadicción y con el sentido de "jeringa" como insidioso) señalaba: "Estos imperialistas no son los únicos que han fertilizado tierras incultas. Si sabré yo... [salto de viñeta] ...lo que me ha costado cultivar... [salto de viñeta] ...mi jardincito de marihuana". El chiste ilustraba una nota del ensayista francés Jacques Ellul, "La revolución deshumanizada”, subrayando las lecturas irónicas del quincenario sobre los izquierdistas (EB, 7 , p. 17). Las drogas eran un problema político generacional, puesto que eran los jóvenes los más expuestos al quiebre de los patrones de racionalidad liberal y de las circunvalaciones ideológicas de símbolos tradicionales de poder y moral, como la Iglesia: "Si la religión viaja a Moscú...”, “...Cierta juventud viaja a la droga” (EB, 4). Como marcamos, en la revista se repetían los comentarios sardónicos sobre el uso de drogas como modo de ironizar sobre una serie de desvíos socio-culturales que devenían inmediatamente políticos. Aquí se cerraba el sentido más oscuro de los diagnósticos del quincenario porteño sobre la juventud, lejos de los jóvenes sobre los cuales buscaba construir un nuevo sujeto político, más allá de la frivolidad de las rebeldías momentáneas o de las modernizaciones vacuas que alimentaban el sentido de base de la palestra de las ironías que surcaban sus páginas.

\section{Burgueses, IDENTIDAD y OtREDADES: A MODO DE CONCLUSióN}

En la tapa del número 52, la revista ironizaba sobre uno de sus blancos preferidos: el justicialismo. “¿Un peronismo burgués?”, se preguntaba de modo retórico ante la imagen de un hombre que leía El Burgués, rodeado por cuatro mujeres que lo miraban con aprobación. Con pantalón gris a cuadros, camisa blanca y blazer, pañuelo al cuello, el petitero lector representaba tanto al burgués de buena vida tal cual la promovía el quincenario como, por eso mismo, al peronista improbable... o imposible (Figura 12). El movimiento liderado por el cuestionado Perón, que reunía múltiples figuras satirizadas por la revista (políticos acomodaticios, sindicalistas de convicciones ambiguas, izquierdistas nacionalistas, católicos tercermundistas o superficiales figuras del espectáculo), aparecía como antítesis de la propuesta burguesa. El sujeto político propuesto por la publicación, lector ya construido en sus gustos por la renovación periodística de la década previa pero burgués a asumirse ideológicamente por medio de la prédica del quincenario, era un hombre blanco que podía ser tanto un joven con prestancia de ejecutivo como un self-made man maduro; podía estar sobriamente casado y con hijos, o ser aún un soltero con aires galantes; podía lucir bajo los cánones del buen vestir tradicional o mostrar sagaces detalles de modernización. Junto a él, la mujer podía responder a criterios de glamour o aparecer bajo una estética más sencilla pero igualmente correcta, tanto como esposa, ama de casa o cita en una salida elegante; incluso, podía ser una mujer de edad madura, antes presente por sus logros que por aparecer centralmente como símbolo de belleza.

Ante ese tejido de representaciones, El Burgués articuló una contra-galería de personajes sobre los cuales caían sus críticas e ironías: hippies, militantes populares, izquierdistas, católicos posconciliares, feministas, guerrilleros, vanguardistas varios. Dentro de ese amplio mapa, la revista jugó permanentemente con las lecturas agonales: así como sus tomas de posición política se determinaban como la identificación contra diversas otredades que actuaban como (para decirlo con el lenguaje de la teoría política) afueras constituyentes, en las órbitas de la sociedad y la cultura el proceder fue idéntico. En ese sentido, la identidad 
aparecía como un constructo complejo, tanto basado en criterios bifrontes como en una articulación entre la derecha liberal-conservadora y criterios de otras derechas, antes combatidas, aunque sin incluir a la derecha peronista en ese esquema. ${ }^{14}$ Ese sentido agonal, expresado en un humor límite marcaba tanto un sentido identitario y un modo expresivo propio de una etapa (y de un proceso ideológico) donde parecía no haber ya sitio para sonrisas más livianas.

En un sentido, la identidad burguesa implicó no sólo las permanentes críticas a esas otredades sino ironizar sobre ellas una y otra vez. El tono ácido que campeó en las páginas del quincenario, en efecto, fue parte central de su discurso político. Como vimos, para El Burgués los cambios en las relaciones de género (básicamente, las transformaciones en los roles de la mujer), las mutaciones en las familias y el quiebre generacional, ejes de este trabajo, fueron parte de una realidad compleja ante la cual sus páginas ofrecieron también respuestas sardónicas, incluso bordeando la misoginia y la estigmatización de la juventud. La crítica en los distintos tonos que proponía Aizcorbe hizo del humor no un agregado del discurso ideológico sino un componente central de este, ora denotado, ora connotado. En los pliegues entre principios ideológicos, posiciones ante la coyuntura, renovación conceptual y representaciones humorísticas, las páginas burguesas expresaron una experiencia representativa de las transformaciones que atravesaban al liberal-conservadurismo argentino, así como de sus implicancias para el universo de las derechas por fuera del tronco liberal, tanto como un caso sumamente peculiar. Precisamente, los temas que hemos recorrido aquí, y el modo humorístico de enfocarlos, resultaron claves en dar al quincenario gran parte de su particularidad e, incluso, para asentarse en su identidad desde posiciones polémicas e incómodas.

El humor chirriante de la revista tocó un límite al publicar una foto de María Estela Martínez de Perón bailando en un club nocturno, como contracara de su sobria figura en la campaña electoral de 1973. Ello provocó que un comando de la derecha peronista colocase una bomba en la redacción, hecho mostrado con detalle en el quincenario. A medida que el proceso político de la Argentina se aceleraba hacia el retorno de Perón al poder, las lecturas de El Burgués se hacían más duras, por ejemplo, colocando a los partidos de La Hora del Pueblo como abanderados de Moscú $(E B, 49)$. Un segundo atentado y amenazas diversas llevaron a que la empresa que imprimía la revista se negara a seguir haciéndolo y el pequeño plantel periodístico se disgregase, lo que selló la suerte de la publicación: el denso clima político de 1973 fue demasiado para un medio gráfico que hizo de la mofa una de sus principales herramientas expresivas.

Si bien Aizcorbe retornó al debate público a finales de la década, con la edición de dos libros ensayísticos desde el proyecto editorial gráficamente denominado 1853 y luego Occitania, ${ }^{15}$ su nombre quedó inscripto en la trama liberal-conservadora como el del director de El Burgués. Al final del complejo período 1971-1973, como en una fábula con moraleja, el burlador debió dejar de reír por las consecuencias de sus bromas, las mismas que le habían forjado una silueta propia en el universo liberal-conservador de esos años.

\section{Figuras}

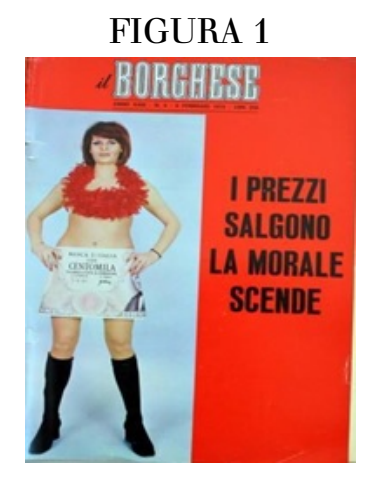




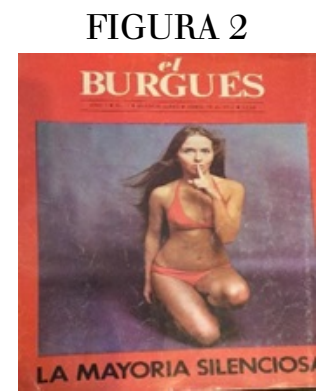

FIGURA 3

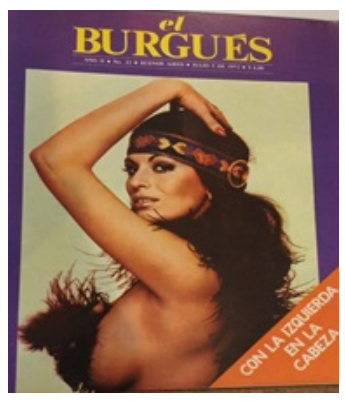

FIGURA 4

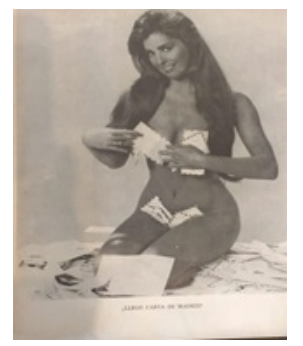

FIGURA 5

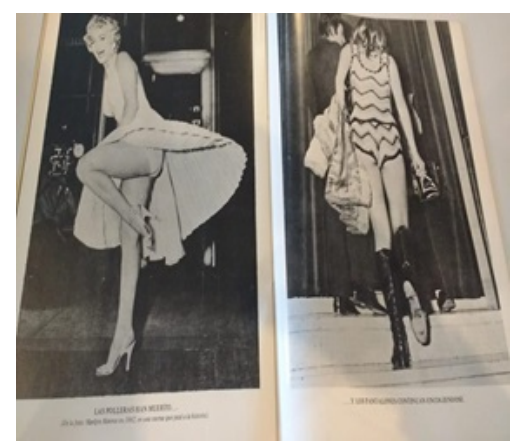

FIGURA 6

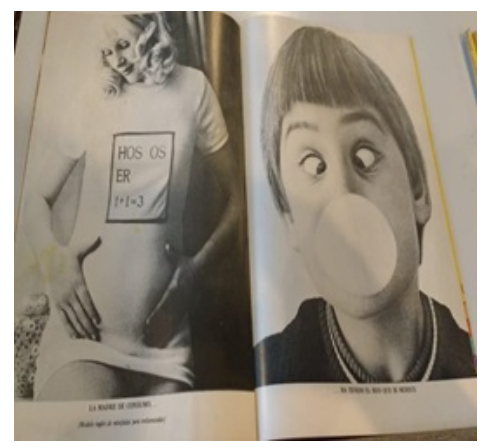


Martín Vicente. "El padre ya no es más El Jefe de la FAMilia”. Género, Familia y Quiebre generacio...

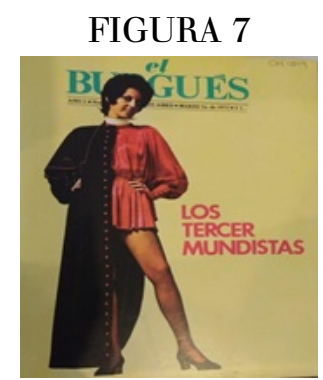

FIGURA 8

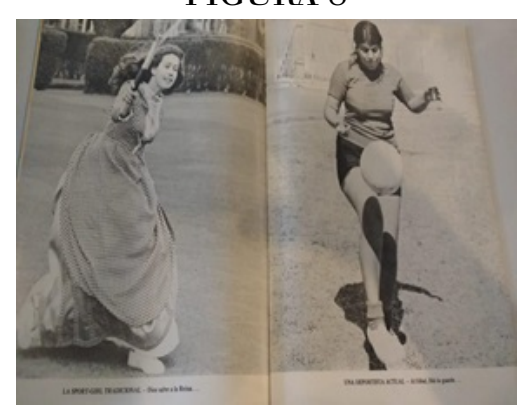

FIGURA 9

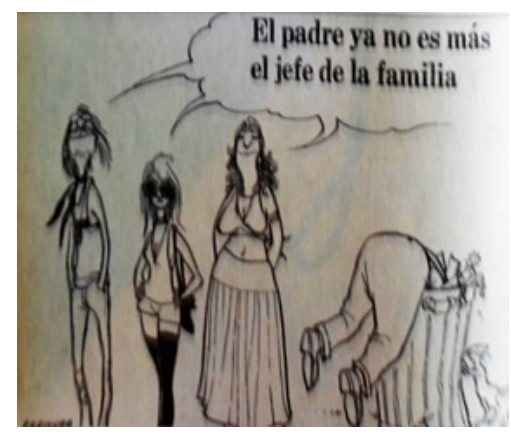

FIGURA 10

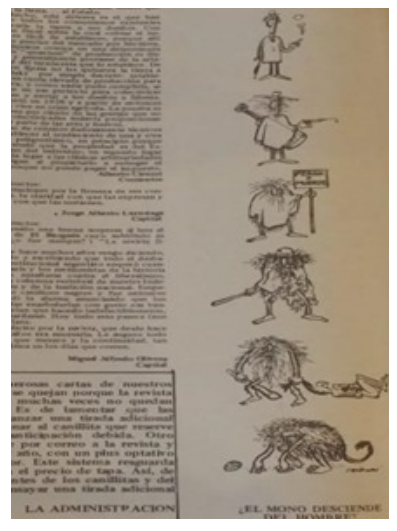

FIGURA 11

BURGUES

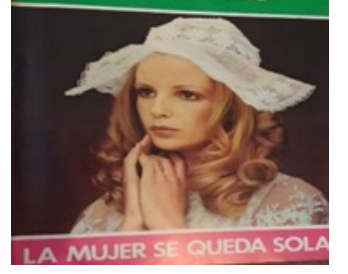




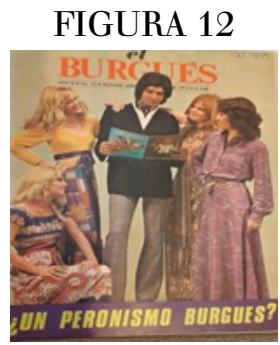

\section{REFERENCIAS}

Adamovsky, E. (2009). Historia de la clase media argentina. Apogeo y declive de una ilusión, 1916-2003. Buenos Aires: Planeta.

Aizcorbe, R. (1976). El mito peronista. Buenos Aires: 1853.

Aizcorbe, R. (1977). Revolución y decadencia. Buenos Aires: Occitania.

Besoky, J. L. (2016a). La derecha también ríe. El humor gráfico en la revista El Caudillo de la Tercera Posición. En Tempo \& Argumento, 8-18, 291-316.

Besoky, J. L. (2016b). La derecha peronista: prácticas y representaciones (1943-1976). Tesis doctoral, Universidad Nacional de La Plata, Facultad de Humanidades, La Plata.

Bohoslavsky, E. y Vicente, M. (2014). Sino el espanto. Temas, prácticas y alianzas de los anticomunismos de derecha en la Argentina, 1955-1966. Anuario del Instituto de Historia Argentina, 14, 1-18.

Bourdieu, P. (2012). La distinción. Criterios y bases sociales del gusto. Buenos Aires: Taurus.

Burkart, M. (2017). De Satiricón a Hum: risa, cultura y política en los años setenta. Buenos Aires: Miño y Dávila.

Calveiro, P. (2005). Politica y/o violencia. Una aproximación a la guerrilla de los años setenta. Buenos Aires: Norma.

Carman, F. (2015). El poder de la palabra escrita: revistas y periódicos argentinos (1955-1976). Buenos Aires: Biblioteca Nacional.

Carnevale, S. (2000). La patria periodística. Buenos Aires: Colihue.

Cosse, I. (2012). Pareja, sexualidad y familia en los años sesenta. Buenos Aires: Siglo XXI.

Cosse, I. (2014). Mafalda: historia social y política. Buenos Aires: Fondo de Cultura Económica.

Cosse, I., Felitti, K. y Manzano, V. (eds.) (2014). Los '60 de otra manera. Vida cotidiana, género y sexualidades en la Argentina. Buenos Aires: Prometeo.

Di Stefano, R. (2010). Ovejas negras. Historia de los anticlericales argentinos. Buenos Aires: Sudamericana.

Di Stefano, R. y Zanca, J. (comps.) (2013). Pasiones anticlericales. Un recorrido iberoamericano. Bernal: UNQ.

Echeverría, O. (2009). Las voces del miedo. Los intelectuales autoritarios argentinos en las primeras décadas del siglo XX. Rosario: Prohistoria.

Eco, U. (1980). Los veinticinco años de Playboy: 5 millones de ejemplares en carne satinada. Análisis, 2, 23-31.

Felitti, K. (2012). La revolución de la pildora. Sexualidad y politica en los sesenta. Buenos Aires: Edhasa.

Galván, V. (2013). El nacionalismo de derecha en la Argentina posperonista. El semanario Azul y Blanco (1959-1969). Rosario: Prohistoria.

Gigena Lamas, C. (1972). Nosotros, los liberales. Buenos Aires: La Bastilla.

González, M. S. (2018). Victoria Ocampo. Escritura, poder y representaciones. Rosario: Prohistoria.

Haidar, V. (2016). El liberalismo y la cuestión de los "hombres libres": un análisis de su problematización en el campo liberal argentino entre 1955 y 1973 . Espiral, 23-66.

Lanusse, A. (1994). Memorias de un general. Planeta: Buenos Aires.

Mansilla, C. (1983). Las fuerzas de centro. Buenos Aires: Centro Editor de América latina. 
Martín Vicente. “El padre ya no es más el jefe de la familia”. Género, familia y quiebre generacio...

Manzano, V. (2017). La era de la juventud en Argentina. Cultura, política y sexualidad de Perón hasta Videla. Buenos Aires: Fondo de Cultura Económica.

McGee Deutsch, S. (2005). Las derechas. La extrema derecha en la Argentina, el Brasil y Chile (1890-1939). Bernal: UNQ.

Mochkofsky, G. (2003). Timerman. El periodista que quiso ser parte del poder (1923-1999). Buenos Aires: Sudamericana.

Morresi, S. (2008). La nueva derecha argentina. La democracia sin politica. Buenos Aires-Los Polvorines: Biblioteca Nacional-UNGS.

Morresi, S. y Vicente, M. (2017). El enemigo íntimo: usos liberal-conservadores del totalitarismo en la Argentina entre dos peronismos (1955-1973). Quinto Sol, 21, 1-24.

Nallim, J. (2014). Las raices del antiperonismo. Origenes históricos e ideológicos. Buenos Aires: Capital Intelectual.

Nash, G. (1987). La rebelión conservadora en los Estados Unidos. Buenos Aires: Grupo Editor Latinoamericano.

Pujol, S. (2002). La década rebelde. Los años 60 en la Argentina. Buenos Aires: Emecé.

Ostiguy, P. (1997). Peronismo y antiperonismo: bases socioculturales de la identidad política en la Argentina. Revista de Ciencias Sociales, 6, 133-215.

Rodríguez, L. (2011). Católicos, nacionalistas y politicas educativas en la última dictadura (1976-1983). Rosario: Prohistoria.

Sitman, R. (2003). Victoria Ocampo y Sur. Entre Europa y América. Buenos Aires: Lumiere.

Scarzanella, E. (2016). Abril. Un editor italiano en Buenos Aires, de Perón a Videla. Buenos Aires: Fondo de Cultura Económica.

Sidicaro, R. (1993). La politica mirada desde arriba. Las ideaspolíticas del diario La Nación (1909-1989). Buenos Aires: Sudamericana.

Vezzetti, H. (2009). Sobre la violencia revolucionaria. Memorias y olvidos. Buenos Aires: Siglo XXI.

Vicente, M. (2014). Una opción en lugar de un eco. Los intelectuales liberal-conservadores en la Argentina, 1955-1983 (Tesis Doctoral). Universidad de Buenos Aires, Facultad de Ciencias Sociales, Buenos Aires.

Vicente, M. (2019). La sonrisa liberal-conservadora. Política, ideología y cambio social en el humor de la revista $E l$ Burgués (1971-1973). Temas y Debates, 37, 67-93.

Zanca, J. (2004). "Curitas pop" y "iturgias a-go-go". El pensamiento anticonciliar en la Argentina de los años sesenta. Ponencia presentada en las IV Jornadas de Ciencias Sociales y Religión, Buenos Aires.

Zanca, J. (2012). El diablo detrás de la risa. "El Peludo" y la caricatura anticlerical en los años veinte. Eadem Utraque Europam, 13, 209-236.

\section{Números de El Burgués consultados}

El Burgués, 1, 28 de abril 1971.

El Burgués, 2, 12 de mayo 1971.

El Burgués, 3, 26 de mayo 1971.

El Burgués, 4, 9 de junio 1971.

El Burgués, 6, 7 de julio 1971, p. 16-22.

El Burgués, 7, 21 de julio 1971, p. 15.

El Burgués, 9, 18 de agosto 1971

El Burgués, 13, 13 de octubre 1971.

El Burgués, 15, 10 de octubre 1971.

El Burgués, 17, 8 de diciembre 1971

El Burgués, 20, 19 de enero 1971. 
El Burgués, 21, 2 de febrero 1972.

El Burgués, 22, 16 de febrero 1972.

El Burgués, 23, 30 de febrero 1972.

El Burgués, 28, 10 de mayo 1972.

El Burgués, 32, 5 de julio 1972.

El Burgués, 39, 11 de octubre 1972.

El Burgués, 40, 25 de octubre 1972.

El Burgués, 46, 17 de enero 1973.

El Burgués, 49, 28 de febrero 1973.

El Burgués, 50, 14 de marzo 1973.

El Burgués, 54, 9 de mayo 1973.

\section{Notas}

* Agradezco a Isabella Cosse por un intercambio sobre los temas abordados y a Mariano Fabris por los comentarios a una versión previa del texto.

1 En las entrevistas a lectores de la época, un otrora militante de la Juventud Peronista y coleccionista de revistas políticas nos señalaba la fascinación que en ellos despertaba El Burgués: "La comprábamos para ver cómo se reían de nosotros" (entrevista con el autor, 2018).

2 Algunos actores particulares, como Victoria Ocampo, hicieron eje en el feminismo y en la temática de la familia, pero su caso fue excepcional (Sitman, 2003; González, 2018).

3 Gigena Lamas editará un libro en la tónica del quincenario durante esos años. Ver Gigena Lamas (1972).

4 Sobre Timerman y Civita, ver Mochkofsky (2003) y Scarzanella (2016). Sobre La Nación, Sidicaro (1993). Sobre el universo del nuevo periodismo, puede verse Carnevale (2000). Para Ideas sobre la Libertad, Haidar (2017).

5 "Envío", El Burgués, 3, 26 de mayo 1971, p. 3

6 Traducir el nombre y reproducir la estética de la publicación italiana creada en la década de 1950 por Leopoldo Longanesi no hacía del quincenario porteño una reversión de la revista peninsular. La estética que Primera Plana (como la de Il Borghese) había tomado de revistas como la estadounidense Time operó como un criterio visual que atravesó la renovación periodística local, superando la de un medio puntual. El tipo de periodismo analítico y "desacartonado" que proponía Aizcorbe era una continuidad de ese parámetro, si bien El Burgués trocaba la atención del nuevo periodismo en crónicas y entrevistas en profundidad por notas de corte teórico e historiográfico.

7 "Envío", El Burgués, 1, 28 de abril 1971, p. 3.

8 "Democracia masoquista", El Burgués, 1, 28 de abril 1971, p. 5.

9 Ese uso estético pareciera aportar un nuevo sentido al proceder que, según Umberto Eco (1980), instauró la revista de Hugh Heffner: transformar lo antes escandaloso en material respetable. Lo que Playboy logró a través de los principales rasgos del nuevo periodismo (crónicas, entrevistas, etc.), El Burgués lo retraducía a los planos del análisis político y la chanza ideológica.

10 Twiggy era el apodo de la modelo y actriz Leslie Lawson, cuya imagen apareció en la segunda mitad de los años sesenta como un nuevo modelo de belleza centrado en la delgadez y el estilo "moderno".

11 "Vaticano modernista", El Burgués, 1, 28 de abril 1971, p. 17.

12 Una amplia literatura sobre los movimientos guerrilleros ha dado cuenta de los complejos procesos de subjetivación implicados en el paso a la opción armada (Calveiro, 2005; Vezzetti, 2009). En la revista era clave la idea de que se trataba de un quiebre en una cultura de izquierda local que antes no había optado por la violencia.

13 Pese a que Japón había participado del Eje junto con las potencias fascistas permanentemente criticadas en la revista, en el quincenario se mostraba una especial consideración a la sobriedad patriótica de los soldados imperiales y a su sentido de respeto a la autoridad, en una centralización del criterio conservador.

14 El desentendimiento era mutuo: para la ortodoxia peronista ellos mismos no estaban en el espacio de la derecha, que identificaban con el liberalismo, sino en el del peronismo auténtico (Besoky, 2016b), terminología sobre la que El Burgués también colocó su mirada cáustica.

15 Ver Aizcorbe $(1976,1977)$. Pese al cambio de nombres, se trató de un mismo proyecto editorial dinamizado por el propio ex director de El Burgués.

\section{BY-NC-SA}

